\title{
KTO SIĘ BOI JonATHANA LitTella?
}

\author{
Marta KoronKIEWicz \\ m.e.koronkiewicz@gmail.com
}

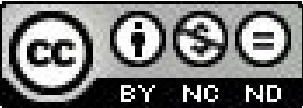

Łaskawe, wydana w 2006 r. (w Polsce w 2008 r.) powieść Jonathana Littella, pod każdym względem stanowi wyzwanie dla czytelnika. Wyzwaniem jest jej objętość - nie lada odwagą trzeba się dzisiaj wykazać, aby zaufać czytelnikowi, że w równym skupieniu przeczyta ponad tysiąc stron. Wyzwaniem jest temat - czy wolno wcielać się w kata? Jak blisko możemy do niego podejść? Czym grozi przekroczenie tej linii? Wyzwaniem, etycznym i estetycznym, jest sam świat przedstawiony - realia wojenne, obozowe, a także pornograficzna wyobraźnia głównego bohatera. Ponad zaś tymi wszystkimi trudnościami i pytaniami, stoi może najciekawsze i najbardziej skrywane wyzwanie: Łaskawe są powieścią stricte współczesna, ponowoczesna, co gorsza są powieścią wciągającą i precyzyjnie skonstruowaną. To machina manipulująca nawykami dzisiejszego czytelnika - tak tego mitycznego „zwykłego”, jak i uzbrojonego w narzędzia, teorie i dyskursy akademika. Poniższy szkic będzie stanowić próbę przyjrzenia się, jak na ową prowokację odpowiedzieli polscy krytycy, co wyróżnili, co pominęli, co potępili. Kontekstem rozważań chciałabym uczynić sformułowaną przez Marianne Hirsch koncepcję postpamięci oraz inne teksty wywodzące się z tzw. memory studies - wydaje się bowiem, że Littell pracuje właśnie na strukturach pamięci, czy, mówiąc dosadniej, obnaża jej mechanizmy, przekształcenia i zniekształcenia. Odwołam się także do uwag Haydena White'a o literaturze świadectwa, Łaskawe bowiem wymuszają po raz kolejny - w imieniu kolejnego pokolenia - dyskusję o literaturze po i o Auschwitz. Szkic zatem będzie stanowić próbę zestawienia zachodnich badań nad pamięcią traumy z polską reakcją na wyzwanie rzucone przez Jonathana Littella w celu odpowiedzi na pytanie: jak temat Zagłady wpływa na sposoby czytania i komentowania tekstu literackiego krytyków różnych pokoleń. Przede wszystkim zaś - jak ogranicza dostrzeganie w tekście jego tekstowości właśnie.

\section{FORMY PAMIĘCI}

Hirsch łączy pojęcie postpamięci z doświadczeniem tak zwanego „drugiego pokolenia”, dzieci i bliskich osób - zarówno ofiar, jak i sprawców - które przeżyły Holocaust ${ }^{1}$. W artykule The Generation of Postmemory pisze: „postpamięć nie jest ruchem, metodą ani idea; widzę ją raczej jako strukturę inter- i transpokoleniowej transmisji traumatycznej wiedzy i doświadczenia. Jest konsekwencją traumatycznego przypomnienia, ale (w odróżnieniu od zespołu stresu pourazowego) na poziomie pokoleniowym" ${ }^{\prime 2}$. Hirsch zauważa, że owa struktura stanowi efekt oscylacji pomiędzy zachowaniem ciagłości a gwałtownym zerwaniem, a zatem w jakiejś mierze między wiedzą a domysłem, jest wynikiem niemożliwej empatii z jednej strony, i nieusuwalnego bagażu doświadczeń z drugiej. To pamięć stworzona, wyobrażona3 ${ }^{3}$ Przede wszystkim zaś - poję-

\footnotetext{
1 M. Hirsch, The Generation of Postmemory, http://www.columbia.edu/ mh2349/papers/generation.pdf, 6.06.2011. Ten i kolejne cytaty z tekstów anglojęzycznych podaję w swoim tłumaczeniu.

2 Tamże.

3 W innym tekście Hirsch zauważa: „[postpamięć jest] przemożną formą pamięci właśnie dlatego, że jej łączność z własnym źródłem jest mediowana nie przez przywołanie wspomnień, lecz przez wysiłek wyobraźni i kreację"; cyt. za: V. Köver, The Shoah Simulacrum: postmemory and spectral homecoming in Maxim Biller's novella "Harlem Holocaust", http://
} 
cie postpamięci, które Hirsch łączy ze słowem „transmisja”, określa rezultat swoistego rodzaju świadomej i nieświadomej komunikacji, stosowania różnych języków, którymi uczestnicy wydarzeń nieopisywalnych przekazują swoje przeżycia. Jak podkreśla badaczka, język mówiony i pisany to tylko jeden z tej grupy, najtrudniejszy, bo wymagający najbardziej intencjonalnego działania. Inne to głównie języki ciała (fobie, przymusy, niekontrolowane odruchy - doświadczenie traumy to wszak doświadczenie opóźnione, powracające, przemawiające nieoczekiwanie), to także języki przedmiotów i obrazów oraz język przemilczeń. Postpamięć to zatem efekt prób łączenia tego, co wiadome - znajomości faktów, a zatem obszaru historii - z tym, co bezpośrednio doświadczane: różnego rodzaju rodzinnymi tabu, zwyczajami i nawykami, w cieniu których dorastały dzieci ofiar i sprawców. Koncepcję Hirsch można jednak odnosić nie tylko do kręgu osób bliskich bezpośrednim uczestnikom wydarzeń, ale do kolejnych pokoleń i do całych społeczeństw. Temat Zagłady bowiem, choć zaczyna być postrzegany jako historyczny, stale wywołuje pytania o samo prawo do „uhistorycznienia”, zamknięcia jako elementu kroniki. Wydaje się, że obecnie - niemal siedemdziesiąt lat od omawianych wydarzeń - problem ten jest jeszcze istotniejszy, głos zabiera już trzecie pokolenie, transmisja staje się coraz bardziej zapośredniczona, pamięć zaś przybiera nowe kształty. Do myśli Marianne Hirsch jeszcze powrócę, teraz jednak warto przywołać Aleidę Assmann, która w tekście 1998 - Między pamięcia a historią podejmuje problem tytułowej granicy i ruchu, który się na niej odbywa, a zatem powrotów tego, co przeszłe, w teraźniejszość i odchodzenia teraźniejszości do historii๋ ${ }^{4}$ Przede wszystkim, Assmann kwestionuje prostą dychotomię historii i pamięci, sugerując, że badania nad narodowym socjalizmem w Niemczech uwrażliwiły naukowców na wielość połączeń, które między tymi dwiema sferami występują. Obszarem badawczym stała się sama historia pamięci, zajmująca się „teraźniejszością przeszłości w świadomości jednostek, grup i narodów”" ${ }^{\prime \prime}$. Badaczka wyróżnia trzy formy czy poziomy pamięci: komunikacyjna, zbiorową i kulturową. Przytoczę ich charakterystyki, klasyfikacja ta bowiem wydaje się szczególnie przydatna dla zrozumienia różnorodności reakcji na dzieło Littella. Pamięć komunikacyjna w tym ujęciu dotyczy jednostki i jej pokolenia, jest „medium indywidualnego przepracowywania doświadczenia”. Ma jednak wymiar komunikacyjny, czyli kształtuje się pomiędzy jednostkami, w wymianie, na fundamencie języka: doświadczenia muszą zostać wyartykułowane i uzewnętrznione a potem ponownie zinternalizowane w ramach małej, bezpośredniej wspólnoty i w określonym czasie (dotyczy jednego pokolenia). Łączy się z tym poczucie nieporównywalności i nieprzekazywalności wspomnień i przeżyć między pokoleniami (wymiana dokonuje się według Assmann co 30-40 lat). W odróżnieniu do biograficznego zaplecza pamięci komunikacyjnej, pamięć zbiorowa opiera się na wiedzy i postawach moralnych, jest efektem działań utrwalających pamięć pokolenia przez powstanie zorganizowanej zbiorowości politycznej i/lub społecznej. Zjawisko to ma charakter sprzężenia zwrotnego: „zbiorowość jest nośnikiem pamięci, a pamięć stabilizuje zbiorowośćc7. Co najważniejsze - jest to pamięć sterowana z zewnątrz, redukcjonistyczna, instrumentalna; polityczna. Najwyższy poziom to pamięć kulturowa: medialna i instytucjonalna, niesiona przez artefakty, a także odrębne, świąteczne porządki czasowe (upamiętnienia materialne i w formie

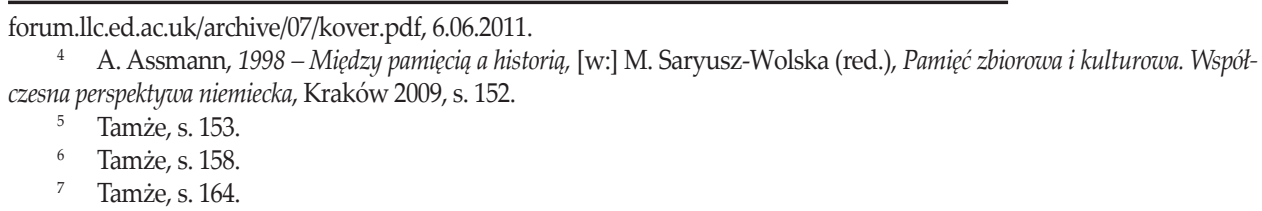


powtarzanych czynności). Jej najważniejszą cechą pozostaje otwartość na interpretacje, dyskusje, ciaggle ponawiane dostosowywanie do teraźniejszości ${ }^{8}$. Jasna i wyrazista klasyfikacja Aleidy Assmann stanowić tu będzie punkt odniesienia.

\section{REAKCJE KRYTYCZNE - KRYZYS REAKCJI?}

Łaskawe „,wywołały do odpowiedzi” zarówno etatowych recenzentów, jak i najwyższej klasy ekspertów i intelektualistów. Wypowiadali się o nich zarówno przedstawiciele pokolenia „pamiętającego", jak i kolejnych generacji: dzieci, wnuków. Z tego powodu starałam się wybrać do - z konieczności skrótowej - analizy recenzje i szkice reprezentatywne dla kilku sposobów myślenia, autorów o różnych specjalnościach i różnych doświadczeniach: literaturoznawcy Michała Głowińskiego (ur. 1934), antropolożki Joanny Tokarskiej-Bakir (ur. 1958), historyka Wojciecha Pięciaka (ur. 1967), krytyczki literackiej i teatralnej Małgorzaty Szpakowskiej (ur. 1940), oraz recenzentów „Dekady Literackiej”, Grzegorza Krzymianowskiego (ur. 1977) i Tomasza Wierusza-Walknowskiego?.

Zacznijmy od dwu najlepszych może tekstów: Głowińskiego i Tokarskiej-Bakir. Antropolożka nazywa dzieło Littella moralitetem dla dzisiejszego świata, współczesną historią Edypa. Dostrzega kliszowość bohatera (np. klisza dobrego SS-mana, nazisty-intelektualisty), podkreśla jego liminalność i cechy wzbudzające „niezdrową fascynację”, prowadzi ją to jednak do wniosku o konieczności użycia „środków nadzwyczajnych”, by przebić się przez „„warstwę moralnego tłuszczu « na sumieniach" - instrumentalizuje zatem jego konstrukcję, uważając za oczywisty cel uświadamiania i przestrzegania. Michał Głowiński tymczasem swój szkic buduje wokół myśli o braku podziału na dobro i zło w świecie Maxymiliana von Aue, jego zdaniem osiągnięciem Littella jest wykazanie, że wszelka moralność jest anachroniczna, pojawia się post factum. Oboje recenzenci zatem uznają etyczny punkt wyjścia za kluczowy do rozważań nad Łaskawymi, oboje także podejmują namysł nad Auem jako postacią pełnokrwista, na swój sposób spójna, przede wszystkim zaś przewrotną i domagającą się od czytelnika zrozumienia. Głowiński otwarcie neguje wyrażoną przez innego krytyka tezę, jakoby bohater Łaskawych miał być jedynie „zlepkiem klisz zaczerpniętych z innych dzieł literatury" ${ }^{\prime 10}$. Dla literaturoznawcy najstarszego pokolenia Maxymilian von Aue jest psychopatą i przykładem osobowości zdolnej do zbrodni („,ktoś, kto w liczącej około tysiąca stron powieści ani na moment nie schodzi z pierwszego planu [...] nie może być schematycznym tworem jak bohater moralitetu czy takiej lub innej odmiany alegorii" ${ }^{\prime 11}$ ), najważniejszym zaś pytaniem pozostaje to, czy ma on prawo do opowiadania o zbrodniach nazistowskich $\mathrm{z}$ własnego, katowskiego punktu widzenia. Choć trudno się z tymi opiniami zgodzić, zwróćmy na razie uwagę na przywołany w nawiasie fragment. Głowiński od samego początku podkreśla, że Łaskawe w żadnej mierze nie powinny być czytane jako alegoria - jak odnieść do tego tezę Tokarskiej-Bakir o Littellu jako autorze współczesnego moralitetu? Łączy się z tym jeszcze jeden problem genologiczny: czy Łaskawe są powieścią historyczną? Choć odpowiedź negatywna

$8 \quad$ Tamże, s. 170-171.

9 M. Głowiński, Od strony kata, „Kwartalnik Artystyczny” 2008, nr 4; J. Tokarska-Bakir, 1939: Littell, „Dwutygodnik. Strona kultury" 2009, nr 12; W. Pięciak, Historia w oczach psychopaty, „Tygodnik Powszechny” 2008, nr 40; M. Szpakowska, 1939: Zrozumieć kata?, „Dwutygodnik. Strona kultury” 2009, nr 11; G. Krzymianowski, Littell vs. cywilizacja. Notatki z procesu, „Dekada Literacka” 2009, nr 3; T. Wierusz-Walknowski, Piekło to my, "Dekada Literacka” 2009 , nr 3.

10 Łukasz Musiał, Unde malum. Wokót „Easkawych" Jonathana Littella, „Przegląd Polityczny” 2008, nr 90, cyt. za: M. Głowiński, Od strony kata..., dz. cyt., s. 114-115.

11 M. Głowiński, Od strony kata..., dz. cyt., s. 114. 
wydaje się oczywista, sposób jej argumentacji wyznacza być może najważniejszą granice między poziomami pamięci, w ramach których funkcjonują komentatorzy. Że do Łaskawych nie należy podchodzić jak do powieści historycznej, najskuteczniej udowodnił Wojciech Pięciak, historyk i znawca problematyki niemieckiej, który właśnie z takim założeniem dzieło Littella próbował przeczytać i który z tego powodu zmuszony został do napisania zjadliwie krytycznej recenzji. Pięciak zarzuca książce nieprawdopodobieństwo fabularne, poziom wiedzy historycznej rodem z Wikipedii oraz epatowanie zupełnie zbędnymi opisami przemocy i seksu, żeby spuentować tekst zaleceniem:

Jeśli ktoś chce doszukiwać się u Littella waloru quasi-pedagogicznego, to już prędzej powinien zachęcić do przeczytania jednej czy drugiej z tych 220 książek historycznych, które Littell, jak sam mówi, przestudiował przed napisaniem Łaskawych. Jest wśród nich wiele takich, które znacznie lepiej opowiadają o tym, jak było ${ }^{12}$.

Pięciak oczekiwał zatem rekonstrukcji. Głowiński zaś dowodzi, że powieść historyczna o Zagładzie po prostu nie jest możliwa. Autor pisze:

Zagłada jest tak traumatyczna i tak straszna, że nie można jej zaszeregować do tych wydarzeń, które były, minęły, zakrzepły czy się ucukrowały. A nie minęły nie tylko dlatego, że żyje jeszcze garstka ocaleńców, którym udało się przejść przez nią, zachowując życie, czy z tej racji, że dopiero w ostatnich dziesięcioleciach zdano sobie w pełni sprawę, czym ona naprawdę była. Jako zespół faktów Zagłada jest czymś zamkniętym, nie jest czymś zamkniętym jako problem, jako zespół pytań, które nieuchronnie się z nią wiąża jako przedmiot refleksji. Powieść historyczna możliwa jest wtedy, gdy o danych wydarzeniach powstało coś, co można określić jako słowo oddalone, nie wiążące się z żywym doświadczeniem, perspektywiczne, jako na swój sposób zamknięta interpretacja (co oczywiście nie znaczy ostateczna czy niezmienna) ${ }^{13}$.

Przytaczam długi cytat, ponieważ wydaje się on kluczowy dla zrozumienia różnicy między pamięcią pokolenia pierwszego i drugiego a kolejnych. Zadajmy sobie bowiem pytanie: czy faktycznie Zagłada nie stała się językiem, zespołem obrazów i skojarzeniowych schematów? A jeśli nie, to czy jest to otwarcie na przeszłość, czy w stronę teraźniejszości i przyszłości? Głowiński uważa, że dyskurs o Holocauście nie spetryfikował się („ucukrował”) i powieść Littella jest tego dowodem. Również Joanna Tokarska-Bakir sugeruje, że Łaskawe pokazują Holocaust jako problem otwarty, nieprzepracowany, „,niewchłonięty”. Nasuwa się wątpliwość, czy to rzeczywiście Łaskawe każą tak myśleć, czy jednak owo przekonanie (i życzenie) nie decyduje o kształcie lektury. Klucz podsuwa kolejna recenzentka, Małgorzata Szpakowska. Podobnie jak Tokarska pisze ona o „nadzwyczajnych środkach”, do których ucieka się Littell (epatowanie złem, przemocą), i podaje podobne usprawiedliwienie tego faktu (bo dzisiaj nic innego „nie zadziała”), używa jednak mocniejszych słów:

Sześćdziesiąt lat później o nowości nie ma mowy, zbrodnia została skonsumowana i strawiona, zawartość masowych grobów z upodobaniem pokazują telewizje, a muzeum w Auschwitz występuje o fundusze unijne na konserwację baraków. Żeby przebić się przez warstwę nie tyle nawet niepamięci, co konfekcji, trzeba - jak widać - sięgnąć po środki nadzwyczajne ${ }^{14}$.

12 W. Pięciak, Historia w oczach psychopaty..., dz. cyt.

13 M. Głowiński, Od strony kata..., dz. cyt., s. 109.

14 M. Szpakowska, 1939: Zrozumieć kata?..., dz. cyt.

\section{OGRODY NAUK I SZTUK}


Szpakowska zatem nie broni się przed myśla, że sposób pamiętania o Holocauście się uschematyzował (świetne pojęcie „,konfekcji”), w Littellu jednak upatruje tego, kto przez ową konfekcję się przedrze. I jeszcze jeden ważny element: Szpakowska podkreśla, że Łaskawe nie zostały napisane dla nas - nas, Polaków i mieszkańców Europy Środkowej; nas, którzy mieliśmy Borowskiego; nas, którzy we wspomnieniach rodzinnych mamy wszyscy ,jakiś Pawiak, jakiś Oświęcim, jaką́s Treblinkę" ${ }^{\prime 15}$. „Littell jednak pisze dla gorzej poinformowanych - wywodzi dalej Szpakowska - pewno dlatego wizerunek zbrodniarza uzupełnia wypisami z lektur. My te lektury mamy od dawna przerobione, ale on urodził się sześć lat po procesie Eichmanna"16. Przytoczone przykłady pokazuja jak sądzę, że mamy tu do czynienia ze stykiem pamięci zbiorowej (instrumentalnej, politycznej) i kulturowej (otwartej na wielość interpretacji, zmiennej) według klasyfikacji Aleidy Assmann. Lektury, które „mamy już przerobione”, miały ukształtować naszą wiedzę o Zagładzie a także nas samych jako zbiorowość. My, ofiary i ich dzieci, wiemy jak było. Młody Amerykanin Littell próbuje, po swojemu, nauczyć tego resztę świata. Czy rzeczywiście istnieje taka granica? Głowiński, Tokarska-Bakir, Szpakowska, a także najmłodszy w tej grupie Pięciak (wykształcenie historyczne jednak zwraca go ku starszemu pokoleniu) czytają powieść Littella jako próbę oddania realiów II wojny światowej w kontrowersyjnej perspektywie sprawcy, zwracają uwagę na jego sposób myślenia (racjonalność w miejsce moralności), wszyscy pytają o źródła Zła - tego pisanego z wielkiej litery - oraz sposoby podtrzymania pamięci o jego zaistnieniu w historii. Łaskawe to dla nich powieść o historii, która jest i powinna być otwarta jako ostrzeżenie dla przyszłych pokoleń.

Tymczasem młodsi recenzenci widzą w powieści Littella coś znacząco innego. Przede wszystkim, podczas gdy, jak starałam się pokazać, dla starszego pokolenia badaczy Łaskawe opowiadają o przeszłości i próbują przywrócić ją doświadczeniu dzisiejszemu, Krzymianowski, Wierusz-Walknowski, a także niewymieniany wcześniej Cezary Michalski czytają tę powieść jako współczesną. Dowodza, że to nie problem jest otwarty (ten dawno już zyskał utrwalony zestaw wyjaśnieńi opisów: banalność zła, efekt Lucyfera, etc.), otwarte zaś jest wydarzenie. „,Książka Littela - pisze Krzymianowski - jest bezpardonową szarżą na cywilizację zachodnią w jej pooświeceniowej wersji, atakiem nie mniej brutalnym, choć lepiej zamaskowanym niż dzieła innego kanonizowanego dzięki opinii skandalisty prozaika - Michela Houellbecqa" ${ }^{\prime 17}$. Wierusz-Walknowski wtóruje:

(...) jest to książka na wskroś współczesna, bowiem materiału do opisu biurokratycznych procedur Zagłady dostarczyła Littellowi, według wszelkiego prawdopodobieństwa, jego praca w organizacjach humanitarnych. W gruncie rzeczy Littell jest pisarzem współczesnym, właściwie może nawet reportażystą (...). Kto raz widział [szczególnie na obszarach pozaeuropejskich] Foucaultiańskie zabiegi szeregowania ludzi i ich potrzeb w imię nadrzędnej racjonalności, ten już nigdy nie przekroczy bramy muzeum w Auschwitz z równie spokojnym sumieniem ${ }^{18}$.

Krzymianowski neguje także zasadność pytania o prawo do mówienia z perspektywy kata i oprawcy, zaznacza, że nie ma to związku z oceną warsztatu pisarza, jest natomiast konsekwencją stale przez Littella powtarzanego -i, dodajmy, obcego większości recenzentów - poglądu od-

\footnotetext{
15 Tamże.

16 Tamże.

7 G. Krzymianowski, Littell vs. cywilizacja..., dz. cyt., s. 95.

18 T. Wierusz-Walknowski, Piekło to my..., dz. cyt., s. 104.
} 
mawiającego „uznania niepowtarzalnego charakteru Holocaustu”"19. Współcześni teoretycy i filozofowie (Foucault, Mirzoeff, Agamben) uznali obóz za paradygmat współczesności. W Homo sacer Giorgio Agamben zauważa, że ogrom zbrodni, która dokonała się w obozach koncentracyjnych przesłania ich prawno-polityczną strukturę, stanowiącą tło i ramę wypadków. Pytając o tę strukturę, włoski filozof podejmuje zadanie trudniejsze od historycznej rekonstrukcji, bo nakierowane na teraźniejszość:

Ta perspektywa pozwoli spojzzeć na obóz nie jako na fakt historyczny, pewną anomalię należącą do przeszłości (nawet jeśli czasem występuje również w chwili obecnej), ale jako swego rodzaju ukrytą matrycę, nomos politycznej przestrzeni, w której obecnie żyjemy ${ }^{20}$.

Obóz, jak go widzi Agamben, jest „hybrydą prawa i faktu, w której oba pojęcia stały się nieodróżnialne"21, stan wyjątkowy staje się w nim regułą. Polityka obozowa współczesnych państw jawi się Agambenowi jako nieodwracalna - tym bardziej więc wymaga opisu. Nicholas Mirzoeff, nowojorski badacz wizualności, po wydarzeniach z września 2001 r. wygłosił wykład zatytułowany Imperium obozów, w którym za model współczesnego świata uznaje obóz dla uchodźców - ucieleśnienie Foucaultiańskiego panoptykonu (kamery przemysłowe jako narzędzie tortury całkowitej widoczności $)^{22}$. W innych tekstach zwraca zaś uwagę na działanie amerykańskich więzień dla terrorystó ${ }^{23}$. Nie miejsce tu na streszczanie tych koncepcii, przywołuję je jednak, by pokazać, że to właśnie taki sposób myślenia kształtuje lekturę powieści Littella przez najmłodsze pokolenie. Najwyraźniej widać to u Krzymianowskiego, kiedy interpretuje Łaskawe jako powieść-zarzut wobec nowoczesnego świata, pisząc:

współczesne państwa, państwa narodowe, ów dziwny wynalazek nowoczesności, są - mniej lub bardziej otwarcie - państwami „totalnymi”, uzurpujacymi sobie prawo do kontroli i dysponowania swymi obywatelami. Siedzimy na tykającej bombie, ba, jesteśmy jej niepozornymi elementami $(. . .)^{24}$.

Konwencja „musimy pamiętać, by Zło się nie powtórzyło" ustępuje tu miejsca myśli o wykorzystaniu pamięci Zagłady dla zrozumienia dzisiejszej polityki i zjawisk społecznych, ponieważ warunki, które umożliwiły zaistnienie obozów, nie zaniknęły wraz z końcem wojny.

Pozostaje jeszcze jeden element do omówienia, czyli sposób w jaki recenzenci komentują formę powieści, jej szeroko pojętą „literackość”. Wydaje się, żei i tutaj podział pokoleniowy zostaje zachowany. Choć Łaskawwe to powieść fikcjonalna, warto przywołać uwagi White'a o literaturze świadectwa:

Zwykle uważa się, że literatura świadectwa dotycząca Holocaustu wnosi wkład do wiedzy na jego temat, a co się z tym wiąże, zazwyczaj przypisuje sięjej status tzw. „literatury faktu”, zaś wartość ocenia się ze względu na rodzaj faktograficznych informacji, których na ten temat dostarcza ${ }^{25}$.

Oceny dzieła Littella pokazuja, że wystarczy samo przywołanie tematu Holocaustu, by „kwestia stylu” stała się kwestią etyczną. Głównym problemem okazuje się narracja pierwszoosobowa, zmuszająca czytelnika do empatii i wywołująca „niezdrową fascynację" pokrętnym

\footnotetext{
19 G. Krzymianowski, Littell vs. cywilizacja..., dz. cyt., s. 98.

20 G. Agamben, Homo sacer. Suwerenna wtadza i nagie życie, Warszawa 2008, s. 225.

21 Tamże, s. 233.

22 N. Mirzoeff, The Empire of Camps, „Situation Analysis" 2002, Issue 1,

http://www.nicholasmirzoeff.com/Images/mirzoeff_EmpireOfCamps.pdf, 6.06.2011.

23 N. Mirzoeff, Invisible Empire: Visual Culture, Embodied Spectacle, and Abu Ghraib, "Radical History Review" 2006, Issue 95, http://www.nicholasmirzoeff.com/Images/Mirzoeff_InvisibleEmpire.pdf, 6.06.2011.

24 G. Krzymianowski, Littell vs. cywilizacja..., dz. cyt., s. 96.

25 H. White, Realizm figuralny w literaturze świadectwa, [w:] tenże, Proza historyczna, Kraków 2000, s. 202.
} 
sposobem myślenia szaleńca i mordercy. Może jednak właśnie lęk przez ową fascynacjąjest tutaj kluczowy. W esejach poświęconych greckiej i rzymskiej seksualności Pascal Quignard pisał:

Na starorzymskich freskach patrycjuszki stoją jak wryte. Spoglądają z ukosa, nieruchome, zastygłe, pochwycone w dramatycznej chwili, której sensu nie rozumiemy. Chciałbym przemyśleć trudne łacińskie słowo fascinatio. Greckie słowo phallos to po łacinie fascinus. (...) Fascinus przyciaga wzrok do tego stopnia, że nie można go odeń oderwać. (...) Fascynacja kosi mowęjak kostucha życie. Fascynacja to martwy punkt języka. Spojrzenie zafascynowane rzuca się zawsze z ukosa ${ }^{26}$.

Spojrzenie z ukosa - spojrzenie speszone własną niestosownością wydaje się charakteryzować podejście części krytyków. Nie dziwi bowiem, że antropolog czyta powieść „naiwnie”, biorąc z niej tylko opowieść i przedstawienie, pomijając natomiast konstrukcyjne, techniczne kulisy (przypadek Tokarskiej-Bakir, choć to ona podkreśla schematy, z jakich składa się postać Auego). Jak jednak wytłumaczyć, że tak wysokiej klasy literaturoznawca jak Michał Głowiński stwierdza jedynie, że, „by rzecz sformułować możliwie najdelikatniej”, powieść ma „ślady kompozycji epizodycznej”"27? Zastanawia owa "delikatność" (czy mamy ją czytać jako konwencję niezdradzania czytelnikowi zbyt wielu informacji, by nie zepsuć efektu, czy jako szczególną ostrożność?), przede wszystkim jednak - dlaczego te uwagi to niemal jedyny komentarz do formy tej rojącej się od chwytów i metaliterackich sygnałów powieści. Jak już pisałam - dla Głowińskiego, tak jak Tokarskiej i Szpakowskiej ważna jest skuteczność. Dlatego też pisze o „poszerzeniu sfery stosowności", a "niezwykłe pomysły i koncepty" przeciwstawia - jako bardziej przekonujące banałowi i kiczowi, które mają stanowić "główne niebezpieczeństwo" dla literatury o Zagładzie. White kwestionował „, przezroczystość" stylu książek Primo Leviego, dowodząc, że właśnie tam, gdzie są najbardziej poetyckie, najpełniej oddziałują na czytelnika, najwięcej mu przekazują ${ }^{28}$. Głowiński, Tokarska i Szpakowska dopuszczają „środki nadzwyczajne”, jeśli od nich zależy moc przekazu. Ich pytanie brzmi: jak pisać, by pamiętać?

Młodsi recenzenci ponownie zachowują się inaczej - obaj zarzucają Littellowi niedociagnięcia stylistyczne (jak pisze Walknowski: docenić należy historyczny rozmach, ale nie po to pisze się powieści), wytykają dłużyzny, narzekają na jakość dialogów, słowem: nie rezygnują ze swojego prawa do oceny warsztatu. Najciekawsze wnioski, nieoczekiwanie, przynosi jednak lektura tekstu Wojciecha Pięciaka. Zarzucając Łaskawym nieprawdopodobieństwo historyczne, autor szkicu dokładnie pokazuje zastosowane przez Littella chwyty fabularne rodem z powieści sensacyjnych i komiksów: ucieczka ostatnim samolotem z oblężonego miasta, nieodzowne „zabili go i uciekł" - czyli kula przebijająca na wylot głowę Auego, znajdowanie się bohatera w centrum wszystkich najważniejszych wydarzeń. Zirytowany Pięciak porównuje jego przygody do opowieści barona Münchausena, tym lepiej określając zaplecze powieści i zasady nią rządzące. Poza mimowolnymi obserwacjami historyka, żaden $\mathrm{z}$ recenzentów nie podjał się przeprowadzenia analizy popkulturowej książki. Czy elementy te są tak nieznaczące czy jednak wygrało poczucie niestosowności, trudno osądzić. A warto chyba zastanowić się, dlaczego opis egzekucji w Babim Jarze przez wielu krytyków został uznany za najbardziej przejmujący ze znanych przedstawień realiów wojennych. Przejmujący to, na marginesie, szczególne słowo, sugerujące oddziaływanie zarówno emocjonalne, jak wręcz fizyczne. Nasuwa się skojarzenie ze scenami filmowymi - to rozmach, nie ascetyzm każą przymykać co jakiś czas książkę, odwracać wzrok.

26 P. Quignard, Seks i trwoga, Warszawa 2002, s. 6.

27 M. Głowiński, Od strony kata..., dz. cyt., s. 110.

28 H. White, Realizm figuralny..., dz. cyt., s. 204-218. 


\section{POSTPAMIĘĆ - PAMIĘĆ CZASU POST}

Zastosowanie przez Marianne Hirsch znaczącego przedrostka post- wydziela swoiste miejsce i czas poza i pomiędzy obiema kategoriami: historii i pamięci. Badaczka pisze:

Postpamięć dzieli warstwową budowę i niewczesność innych „postów”, układając się zgodnie z praktyką cytowania i pośredniczenia, która je chararakteryzuje, zaznaczając moment końca wieku/przełomu wieków jako moment spojrzenia bardziej wstecz niż wprzód i raczej definiowania teraźniejszości w relacji do problematycznej przeszłości niż inicjowania nowych paradygmatów²9.

\section{JaK ISTNIEJe Aue?}

Obersturmbannführer to model stabilnej, uporządkowanej tożsamości, w który wpisany mógł być każdy Niemiec. W tym Max Aue, przeintelektualizowany, egzaltowany prawnik francusko-niemieckiego pochodzenia. Spójrzmy więc, jak „„działa” tożsamość bohatera powieści Littella.

Po pierwsze - Aue jest bliźniakiem swojej siostry. Od dzieciństwa towarzyszy mu poczucie istnienia połowicznego, niepełnego. Tak rodzi się fascynacja jego kobiecym odbiciem: Uną. Ich zabawy stają się coraz bardziej podszyte erotyzmem, dosłownym szukaniem ponownego złączenia. Obsesyjna miłość do siostry, od której Aue zostaje oddzielony - przez rodziców, ale i przez samą Unę, która traci zainteresowanie bratem - staje się dla bohatera Easkawych podstawowym, konstytuującym go doświadczeniem; Bataille'owską transgresja, o której Aue będzie marzyć. Jest to miłość braku, pożądanie, które po utracie obiektu przeradza się w maniakalne pragnienie stania się owym obiektem. Aue fantazjuje o byciu Uną o jej doświadczeniach seksualnych - co prowadzi go do homoseksualizmu. Doktor praw zostaje biernym gejem - poszukuje chłopców, którzy, kochając się (?!) z nim, pozwoliliby mu poczuć się jak kobieta. Po jednym z takich kupionych gwałtów Aue trafia na posterunek, gdzie - jak sam mówi - ze spermą w tyłku zostaje SS-manem. Upodlająca sytuacja, w której się znajduje, pcha go ku dalszej uległości. Uległości, która wprowadzi go w matrycę tożsamości normatywnej: aryjczyka, nadczłowieka, ukochanego obrońcy swojej rasy. Tak zaczyna się historia schizofrenii Maxa Aue. Jego niestabilna seksualność, niepewna płciowość pokryte zostają czarnym mundurem oficera.

Aue to przypadek queerowej nie-toż-samości w sytuacji opresywnej. III Rzesza z ideologią selekcji ludzi, ze swoją wyjątkowo wyczulona, tyle że negatywnie, wrażliwością na odmienność staje się u Littella metaforą wszelkiej normatywności, każdego uporządkowania. Bohater ostatecznie zaczyna utożsamiać się z pożądaną rola, staje się rzetelnym, pracowitym i zaangażowanym nazistą. Nowa tożsamość zaczyna wypierać rozedrganą wielość poprzedniej, spychać ją ku nieświadomości. To, co zepchnięte, wraca jednak - jako kanoniczne Freudowskie niesamowite - w popelnianych niejako poza świadomością kolejnych morderstwach. Obersturmbannführer Aue nie zabija własnoręcznie nikogo (czyni to na papierze). Jako Max, brat Uny, zabija jednak wszystkich, którzy mogliby podważyć jego stabilną tożsamość: matkę, ojczyma, kochanka, przyjaciela. Orestes krzyżuje się z Edypem. To, co nieświadome, zdaje się podmywać i rozpuszczać wszelkie zdecydowanie Auego, spychając go w szaleństwo. Jego maniackie przywiązanie do fizjologii- usprawiedliwiane czasem wojennymi warunkami - to kolejny moment wracania odrzuconych fantazji. Aue jawi się tu jako postać abiektalna, fascynują go wydzieliny, sam proces wydalania, brutalny seks. Zbliża go to nie tylko do sadystycznych kapo z obozów, ale także - przede wszystkim - do ściśle z ciałem związanej własnej seksualności. Max Aue nie pożąda nikogo, a raczej - ze wstrętem - pożąda siebie samego. Jego marzeniem staje się samowystarczalność: marzy niemal o heteroseksualnym stosunku między sobą męskim a sobą kobiecym (droga od szukania stosunku z siostrą po szukanie stosunku z nazistą w sobie).

29 M. Hirsch, The Generation of Postmemory..., dz. cyt. 
Mimo to Aue próbuje w pełni wcielić się w rolę prawdziwego Niemca. Początkowo racjonalizuje homoseksualizm, z wyjątkową zręcznością wykorzystując dialektykę nazistowską. Później stara się nawet spotykać z kobietą. Wszystko to jednak pozostaje na powierzchni munduru i silnego ciała reprezentatywnego SS-mana, nie mając dostępu do marzaccego o upodleniu bezbronnym ciele Maxa-Uny. Wierząc w oba systemy: selekcjonując i będąc wykluczonym, Aue rozdwaja się ostatecznie. Czy popada wówczas w całkowity obłęd czy ślepą intuicją uruchamia w sobie - jak autopilota - instynkt przetrwania, zależy od interpretacji.

\section{ŚMIECH I ŚMIERĆ}

Queer, Bataille, Freud, abiektalność według Kristevej - to najbardziej oczywiste skojarzenia, a przecież nie jedyne. Ponadto mamy przecież jeszcze mitologię, kliszę wrażliwego nazisty (jak choćby z Pianisty), kliszę pięknego nazisty (mundury projektu Hugo Bossa), teorie liminalości przywoływane przez Tokarską-Bakir. Littell - odwołując się do znanych chwytów, schematów literatury popularnej, dyskursów humanistycznych, motywów mitologicznych, mieszając fakty i fikcję, tworząc "historie alternatywne” - tworzy właściwie apologię narracji i jej mocy, a jednocześnie ją podważa i wyśmiewa. Choć boimy się przyznać, Łaskawe to powieść głęboko ironiczna, wykorzystująca wszystkie czytelnicze odruchy i narzędzia i zwracająca je przeciwko nam. Powieść - postmodernistyczna zabawka, którą z taką radością bawilibyśmy się, gdyby nie paraliżowało nas poczucie, że nie uchodzi. Że, parafrazując słowa Primo Leviego przytaczane przez White'a, takie czytanie to dowód choroby psychicznej lub/i moralna nieprzyzwoitość.

Na koniec warto przywołać lekkie i niezobowiązujące w formie, lecz może najodważniejsze o niej rozważania pióra Michalskiego. Cytaty będą trzy: odważny, słuszny i autoironiczny.

Pierwszy:

Przy lekturze Littella, jak zwykle nie dość głęboko przeczytanego, niezinterpretowanego i nieprzyswojonego przez "skotłowanych Polonusów" (...), przychodzi do głowy zupełnie naturalne rozwinięcie dość zbanalizowanych pytań, w rodzaju: „,Czy po Auschwitz można wierzyć w Boga? Czy po Auschwitz można pisać poezję...?”. Rozwinięcie oczywiste: „Czy po Auschwitz można uprawiać seks?"'30.

Drugi:

(...) Auschwitz należałoby traktowaćjako synekdochę większej całości. Całego naszego urzeczowienia. Całej naszej pamięci ${ }^{31}$.

Trzeci zaś jest nieco wyrwany z kontekstu, a jednak wydaje się bardzo Littellowski. Michalski bowiem, pisząc o przeżywaniu lektury Łaskawych w samotności, podkreśla, że to lektura „,bez kogokolwiek, z kim wspólnie można by wyśmiać Agambenowskie (przypominające także Borowskiego) rozważania Obersturmbannfuehrera doktora Aue: o kapo, komendantach obozów, bohaterach wojennych, ofiarach, pracownikach korporacji Speera... O wszystkich tych ludziach wymieniających się miejscami na wielkiej karuzeli samouprzedmiotowienia" ${ }^{\prime \prime 2}$. W powyższym szkicu sugerowałam, że trop Agambenowski wydaje się ciekawszy niż dyskurs upamiętniania. Jak pokazuje jednak Michalski - jest on tak samo oczywistym językiem czytania tej powieści, co inne, z równą precyzją zaprogramowane przez Jonathana Littella. Oczywistym po śmieszność. Być może jednak najgroźniejszy i najbardziej zbawienny dla naszej ustabilizowanej, wytworzonej pamięci jest właśnie śmiech.

30 C. Michalski, Dziennik, „Krytyka Polityczna” 2010, nr 22, s. 273.

31 Tamże.

32 Tamże, s. 268. 
U granic śmiechu człowiek przestaje chcieć być wszystkim i chce być wreszcie tym, kim jest, istotą niedoskonałą, nie dokończona, dobra, o ile potrafi, aż po momenty okrucieństwa; i jasnowzroczną... aż po śmierć ślepca ${ }^{33}$.

\section{BiBLIOGRAFIA}

Littell J., Easkazwe, Kraków 2008.

Agamben A., Homo sacer. Suwwerenna władza i nagie życie, Warszawa 2008.

Assmann A., 1998 - Między pamięcia a historia, [w:] M. Saryusz-Wolska (red.), Pamięć zbiorowa i kulturowa. Wspótczesna perspektywa niemiecka, Kraków 2009.

Bataille G., Doświadczenie wewnętrzne, Warszawa 1998.

Głowiński M., Od strony kata, „Kwartalnik Artystyczny” 2008, nr 4.

Krzymianowski G., Littell vs. cywilizacja. Notatki z procesu, „,Dekada Literacka” 2009, nr 3.

Michalski C., Dziennik, „Krytyka Polityczna” 2010, nr 22.

Quignard P., Seks i trwoga, Warszawa 2002.

White H., Realizm figuralny w literaturze śziadectwa, [w:] tenże, Proza historyczna, Kraków 2000.

Wierusz-Walknowski T., Piekło to my, ,"Dekada Literacka” 2009, nr 3.

\section{Netografia}

Hirsch M., The Generation of Postmemory, "Poetics Today" 2008, http://www.columbia.edu/ mh2349/papers/generation. pdf, 6.06.2011.

Köver V., The Shoah Simulacrum: postmemory and spectral homecoming in Maxim Biller's novella "Harlem Holocaust", http:// forum.llc.ed.ac.uk/archive/07/kover.pdf, 6.06.2011.

Mirzoeff N., Invisible Empire: Visual Culture, Embodied Spectacle, and Abu Ghraib, „Radical History Review” 2006, Issue 95, http://www.nicholasmirzoeff.com/Images/Mirzoeff_InvisibleEmpire.pdf, 6.06.2011.

Mirzoeff N., The Empire of Camps, "Situation Analysis" 2002, Issue 1, http://www.nicholasmirzoeff.com/Images/mirzoeff_ EmpireOfCamps.pdf, 6.06.2011.

Pięciak W., Historia w oczach psychopaty, „Tygodnik Powszechny” 2008, nr 40; http://czytelnia.onet.pl/0,1510460,4,artykuly.html, 6.06.2011.

Szpakowska M., 1939: Zrozumieć kata?, „Dwutygodnik. Strona kultury” 2009, nr 11; http://www.dwutygodnik.com/artykul/390-1939-zrozumiec-kata.html, 6.06.2011.

Tokarska-Bakir J., 1939: Littell, „Dwutygodnik. Strona kultury” 2009, nr 12; http://www.dwutygodnik.com/artykul/415-1939-littell.html, 6.06.2011.

\section{Słowa kluczowe}

Littell, postpamięć, memory studies, metakrytyka, Łaskawe, metodologie czytania, recepcja krytyczna

\section{STRESZCZENIE}

Artykuł przedstawia analizę zestawu recenzji i szkiców krytycznych, które ukazały się w polskiej prasie po wydaniu powieści Jonathana Littella Łaskawe. Korzystając z narzędzi oferowanych przez tak zwane memory studies oraz koncepcji postpamięci autorstwa Marianne Hirsch, autorka bada powody różnego typu przemilczeń i swoistej autocenzury, którymi charakteryzują się owe teksty. Powieść Littella w tym ujęciu okazuje się prowokacja, na którą bardzo różnie odpowiadają krytycy różnych pokoleń. Również od przynależności do pokolenia zależy - jak pokazują analizowane teksty - sposób ujmowania i rozumienia Zagłady jako wydarzenia historycznego i otwartego problemu poznawczego. Druga część szkicu wykazuje, że Jonathan Littell konstruuje swoją powieść, biorąc za podstawę mechanizmy społecznej i kulturowej pamięci, których struk-

33 G. Bataille, Doświadczenie wewnętrzne, Warszawa 1998, s. 85. 
tura nie jest wolna od schematów, klisz, stów-kluczy. Powieść okazuje się wymierzona specjalnie w nowoczesne i ponowoczesne metodologie czytania, który to fakt nie został właściwie zauważony ani zinterpretowany przez krytyków (którzy sami jednak z owych metodologii korzystali).

\section{WhO IS AFraid OF JonAthan LITTLEL?}

\section{Keywords}

Littel, post-memory, memory studies, meta-criticism, The Kindly Ones, methodologies of reading, critical reception

\section{Summary}

The paper presents the analysis of a set of reviews and critical essays, which have been published in the Polish press after the publication of Jonathan Littel's novel The Kindly Ones. Using the tools offered by the so-called "memory studies" and the Marianne Hirsch's concept of post-memory, the author examines the reasons of various suppressions and peculiar self-censorship, which characterise those texts. The Littell's novel in this depiction turns out to be a provocation, to which critics of different generations respond very differently. What is also a result of their belonging to a certain generation is the way in which they display the analyzed texts and the way of grasping and understanding the holocaust as a historical event and an open cognitive problem. The second part of the essay proves that Jonathan Littell constructs his novel basing on the mechanisms of social and cultural memory, which's structure is not free of schemes, clichés and key-words. The novel turns out to be purposely aimed at the modern and postmodern methodologies of reading, which is a fact that has not been properly noticed and interpreted by the critics (who, however, have themselves used those methodologies). 